\title{
Recent Developments in Seedless Grapevine Breeding
}

\author{
M. Akkurt*, H. Tahmaz, S. Veziroğlu \\ Department of Horticulture, Faculty of Agriculture, Ankara University, Ankara, Turkey
}

Date of submission for publication: January 2019

Date of acceptance for publication: March 2019

Keywords: Grape, seedlessness, breeding, variety

Grapes are one of the most commonly produced fruit crops in the world and are consumed as table grapes, wine grapes and dried grapes. In line with consumer demands, seedlessness continues to be an important feature that increases the chances of marketing grapes. Nearly all of the dried grapes that are offered to the world markets are seedless grapes. In addition, the demand for seedless varieties has increased steadily in the table grape trade over the years. Therefore, the production of new seedless grape varieties with large berries that are suitable for table consumption is one of the important goals of breeding studies in viticulture. In this study, recently bred and released new seedless grape varieties are briefly introduced, seedless grape breeding methods are summarised, and the latest developments in breeding methods are explained.

\begin{abstract}
INTRODUCTION
Consumer demand for seedless grape varieties - both dried and table grapes - has been increasing worldwide. Almost all of the dried grapes consumed in the world markets consist of seedless grape varieties. In principle, seedlessness is produced in two mechanisms: through parthenocarpy and through stenospermocarpy. Seedless fruit set occurs without fertilisation and pollination in parthenocarpic fruit set (Perl et al., 2000). Parthenocarpic grape varieties are not preferred in the market due to their small berry size, while stenospermocarpic varieties experience a greater demand due to both table fruit and dried fruit quality. In stenospermocarpic fruit set, fertilisation and pollination occur normally as in the case of seeded grape varieties. However, with genetically controlled mechanisms, the development of integuments in the ovules after pollination is prevented. As a result of degeneration of the embryo and then the endosperm, seed development stops, with only partially formed seeds or seed traces being left (Costantini et al., 2008).
\end{abstract}

\section{INHERITANCE OF SEEDLESSNESS}

Different hypotheses have been proposed to determine the inheritance of seedlessness in grapevines. While some researchers have stated that seedlessness is controlled by recessive genes, another group of researchers has reported that it is controlled by different numbers of dominant genes (Constantinescu et al., 1972, Spiegel-Roy et al., 1990, Sato et al., 1994, Ledbetter \& Burgos, 1994). In recent years, the most accepted model for the inheritance of seedlessness is that seedlessness is controlled by three independent recessive genes that are regulated by a dominant gene named SdI (seed development inhibitor) (Bouquet \& Danglot, 1996,
Lahogue et al., 1998, Adam-Blondon et al., 2001, Doligez et al., 2002).

\section{SEEDLESS GRAPE-BREEDING METHODS}

The breeding of seedless, colourful, disease-resistant new grape varieties with large berries is one of the important topics studied in viticulture. In addition to traditional methods such as clonal selection and conventional crossbreeding, biotechnological methods such as embryo rescue techniques and polyploidy have gained importance in seedless grape breeding. Furthermore, supportive genetic techniques, such as early selection with molecular markers in conventional crossbreeding, have also started to be used widely in seedless grape breeding (Değirmenci \& Marasalı Kunter, 2007).

\section{Conventional crossbreeding}

In conventional crossbreeding studies on breeding seedless grape varieties, a seedless parent is used as the father (pollinator) and a seeded parent is used as the mother. However, in seeded $x$ seedless crosses, the seedlessness rate obtained in the progeny is, varying between $0 \%$ and $49 \%$, depending on the parental combination (Spiegel-Roy et al., 1990). The successful culture of the abortive embryos of stenospermocarpic grapevine varieties has enabled seedless $\mathrm{x}$ seedless crosses in conventional crossbreeding studies. This practice (embryo rescue technique) has increased the rate of seedlessness observed in $F_{1}$ plants in seedless $x$ seedless crosses, and the seedlessness rate in the progeny has ranged from $16.7 \%$ to $92 \%$, depending on the parental combination (Ramming et al., 1990). During the past 30 years, embryo rescue has been used mostly in seedless grapevine breeding 
programmes in the United States, Israel, South Africa, Chile and Australia. "Prime", "Mystery", "Spring Blush" and "Black-finger" are seedless table grape cultivars developed in Israel (Perl et al., 2003). Similarly, many studies have been published in the literature reporting the successful use of the embryo rescue technique in crossbreeding studies in viticulture (Ramming et al., 2000; Yang et al., 2007; Tian \& Wang, 2008; Ji \& Wang, 2013; Uquillas et al., 2013; Li et al., 2014, 2015).

Many seedless grape varieties obtained by conventional crossbreeding studies have been offered to the world grape market. The names of some of these table grape varieties and parental breeds are as follows: Autumn Royal (Autumn Black x Fresno C74-1; black), Beauty Seedless (Koenigin der Weingaerten $\mathrm{x}$ Black Kishmish; black), Crimson Seedless (Emperor x Fresno C33-199; Red-black), Fantasy Seedless (Fresno B 36-27 x Fresno C 78-68; black), Flame Seedless ((Cardinal x Sultanina) X (Red Malaga x Tifafihi Ahmer) X (Muscat of Alexandria x Sultanina); red), Ruby Seedless (Emperor x Sultana Moscata; red), Scarlet Royal (C33-30 x C103-41; red), Sunred Seedless (Datal x Ruby Seedless; red), Sweet Scarlet (C33-30 x C51-63; red), Superior Seedless (Cardinal x ? (seedless variety), white) (Julius Kühn Institute, 2018a).

\section{Marker-assisted selection in crossbreeding}

Since breeding by the conventional crossbreeding method requires a long time and high costs, studies on the development of selection with the help of DNA-based markers have gained importance in recent years. In this context, the segregation of seedless genotypes in the progeny obtained by the crossbreeding of seeded and seedless parents is performed with the help of molecular markers. Based on the hypothesis proposed by Bouquet and Danglot (1996), Lahogue et al. (1998) developed a codominant SCAR (sequence characterised amplified region) marker called SCC8, and it was successfully used for the segregation of seeded $\mathrm{x}$ seedless hybrid genotypes. In a study by Mejía and Hinrichsen (2003), the dominant SCAR marker, called SCF27, was used for selecting seedless progeny in Ruby Seedless x Sultanina hybrids.

Significant progress has been made in the development of molecular markers in grapevines over the past two decades. Linkage groups related to berry size and seedlessness in grapevines were detected in the quantitative trait loci (QTL) maps obtained from different seedless parental combinations (Doligez et al., 2002; Fanizza et al., 2005; Cabezas et al., 2006; Mejía et al., 2007; Costantini et al., 2007, 2008). Two of these were identified on linkage group 18 (LG18), and one on linkage group 4 (LG4) (Dai et al., 2011). Cabezas et al. (2006) developed a genetic map from the F1 combination obtained from the crossbreeding of the conventional, seeded $V$. vinifera variety "Dominga" and the seedless variety "Autumn Seedless". The QTL map indicated a large QTL region in the linkage group 18 associated with the seedlessness trait, and VMC7F2 was reported as the SSR marker closely associated with this QTL region. It was claimed that the VMC7F2 marker could be used in marker-assisted selection (MAS) for early detection of seedless individuals in breeding. Costantini et al. (2008) confirmed this finding after QTL analyses for berry size and ripening time in grapevines, and identified VMC7F2 as the most closely associated marker with the SdI locus. Followed by further research, papers have been published on the successful use of the VMC7F2 marker in breeding studies on seedlessness. Akkurt et al. (2012) found that the $198 \mathrm{bp}$ allele from the VMC7F2 marker in the "Muscat Hamburg" $\mathrm{x}$ "Sultani" hybrid population was closely associated with seedlessness in the F1 generation and stated that it could be used for MAS in the early selection of seedlessness. Karaağaç et al. (2012) indicated that the $198 \mathrm{bp}$ allele and the VMC7F2 marker could be used successfully in the selection of seedless individuals in segregations, and that the progeny size could be reduced to $54 \%$.

Based on their study, involving sequence analyses, sequence characterisation and transcriptional analyses, Mejía et al. (2011) suggested that VvAGL11 was the major functional candidate gene in seedlessness. The researchers reported that VvAGL11 was the major locus for seedlessness in Vitis vinifera varieties, similar to AGL11 from the D-lineage MADS-box family responsible for seed development in different plant species, and developed a series of STS (sequence tagged site) markers associated with this gene. The P3-VvAGL11, which is one of the developed markers, was determined to be used effectively in the early detection of stenospermocarpic seedlessness in grapevines. Bergamini et al. (2013) used the VvAGL11 marker in the $\mathrm{F}_{1}$ genotype of 475 seeded $x$ seedless crosses and indicated that the marker can be used in all seedless phenotypes.

\section{NEWLY BRED SEEDLESS GRAPE VARIETIES}

There are a total of 67 seedless grape varieties that have been bred since 2000 and recorded in the VIVC database. Of these varieties, 66 are table varieties and one is a wine grape variety. Most of the varieties have been registered in the USA, followed by Turkey, Brazil, China, South Korea and South Africa. The bred varieties and their parents are presented in Table 1.

\section{CONCLUSION}

The primary traits on which the focus is in the development of new varieties in grapevine-breeding studies are seedlessness, berry size, high quality, resistance to diseases, earliness and lateness, and resistance to stress conditions. In addition to conventional breeding methods in seedless grape breeding, biotechnological approaches have gained importance in recent years. The use of in vivo growth-regulating agents, along with the embryo rescue method, has led to a significant improvement in the survival of abortive ovules.

Especially in seedless grape breeding, the use of genetic markers has gained great importance in its contribution to selection studies. Various researchers have reported that, while VMC7F2, one of the SSR markers, can be used successfully in the early selection of seedless varieties, the p3-VvAGL11 STS marker can be used more effectively in MAS. In this way, the long-term, labour-intensive and costly grapevine-breeding studies can be made shorter and more effective. While studies focusing on the development of new seedless varieties are concentrated mainly in the USA, Turkey, Israel, Italy and China, studies on developing 


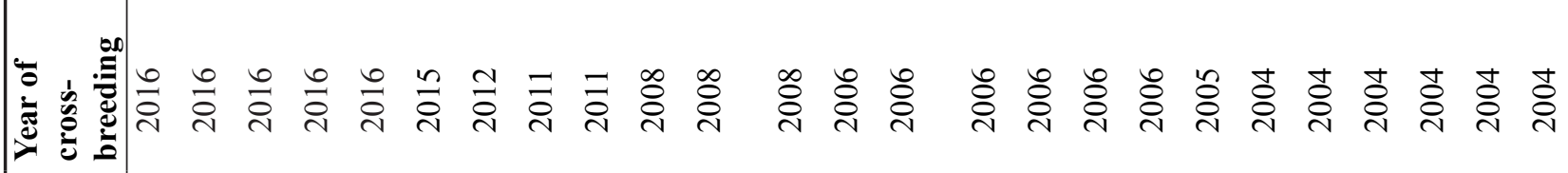

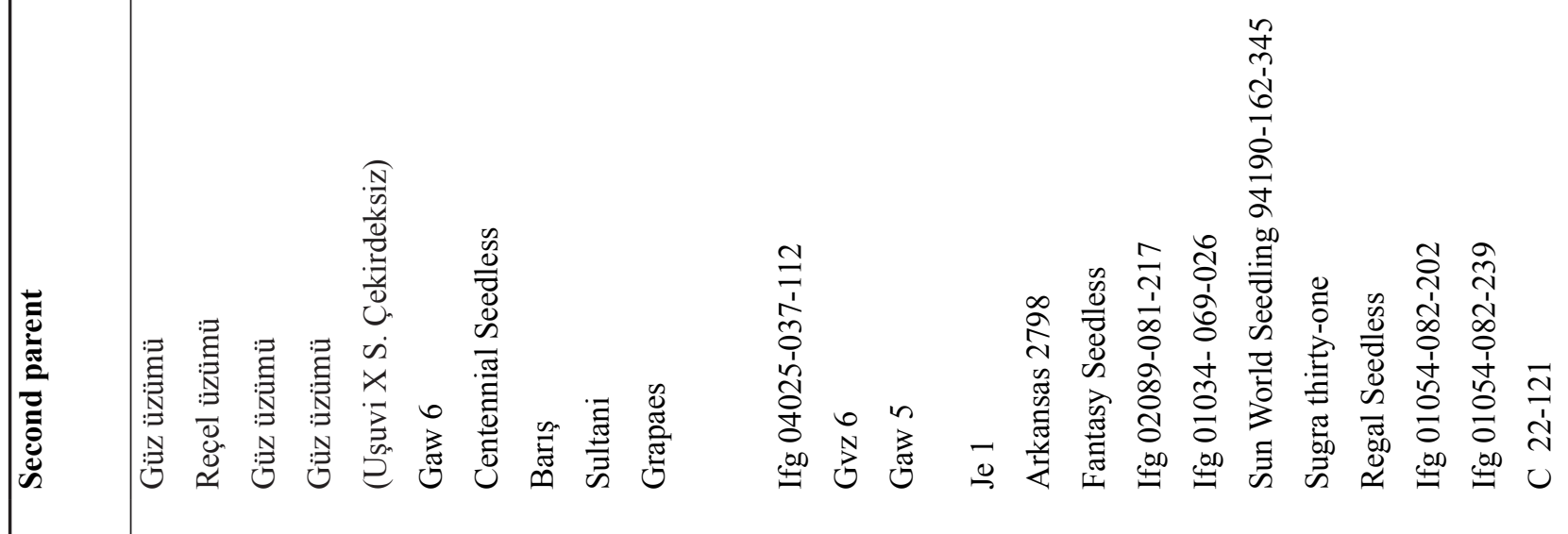

$\frac{\dot{\infty}}{\overrightarrow{2}}$

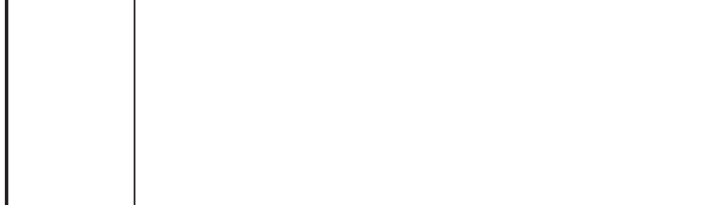

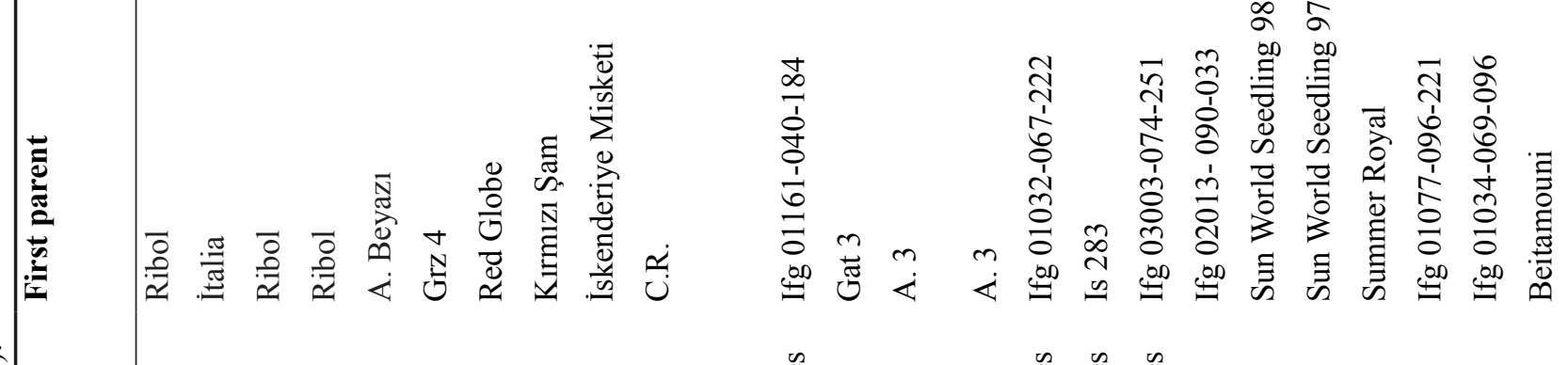

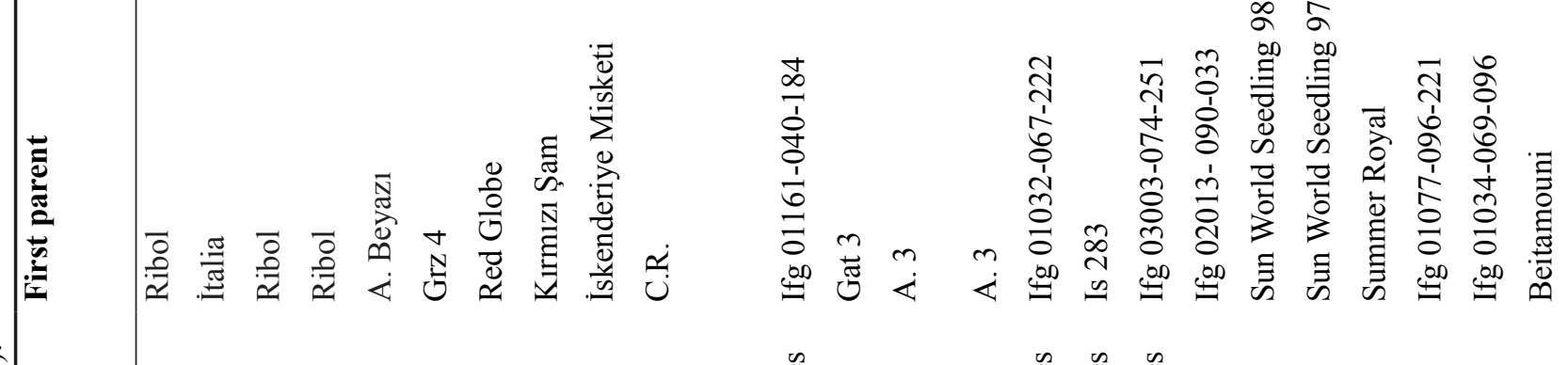

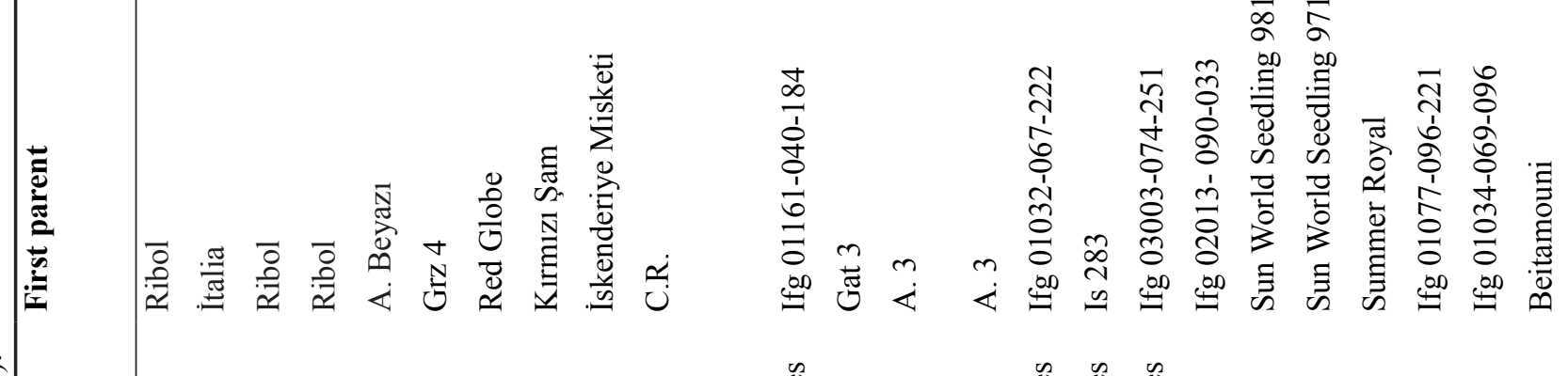

in 2

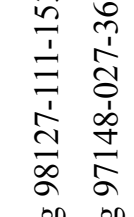

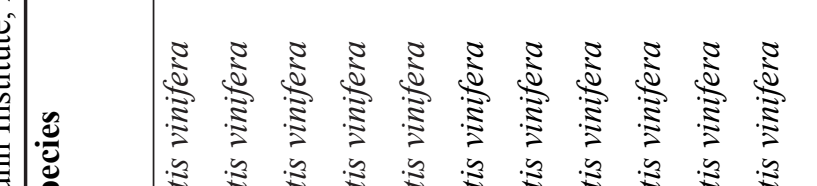

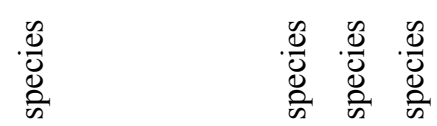

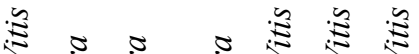

递

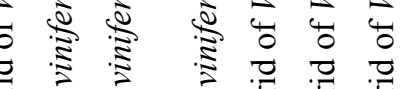

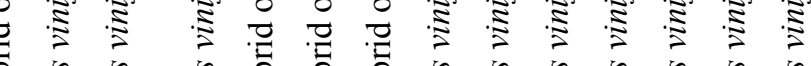

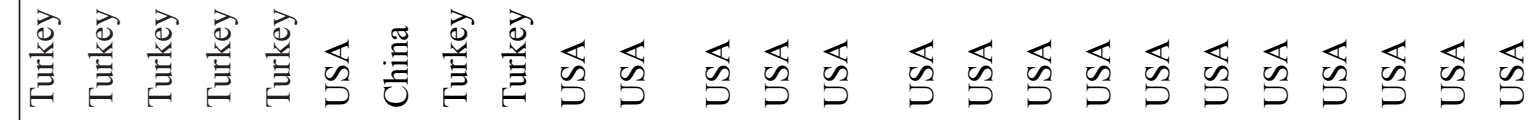

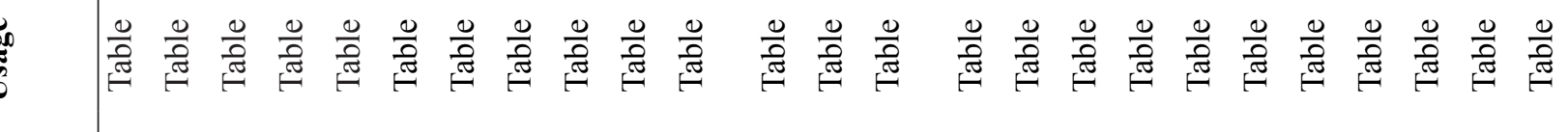

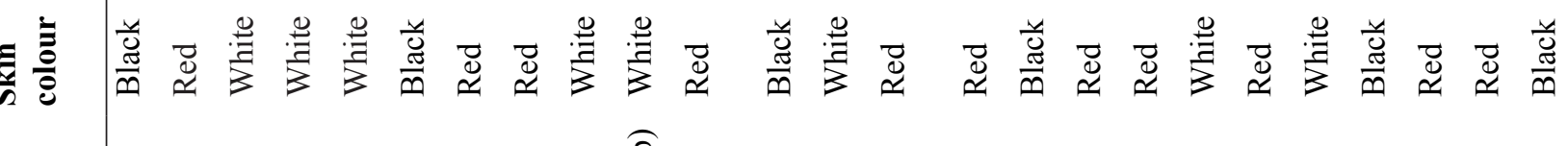




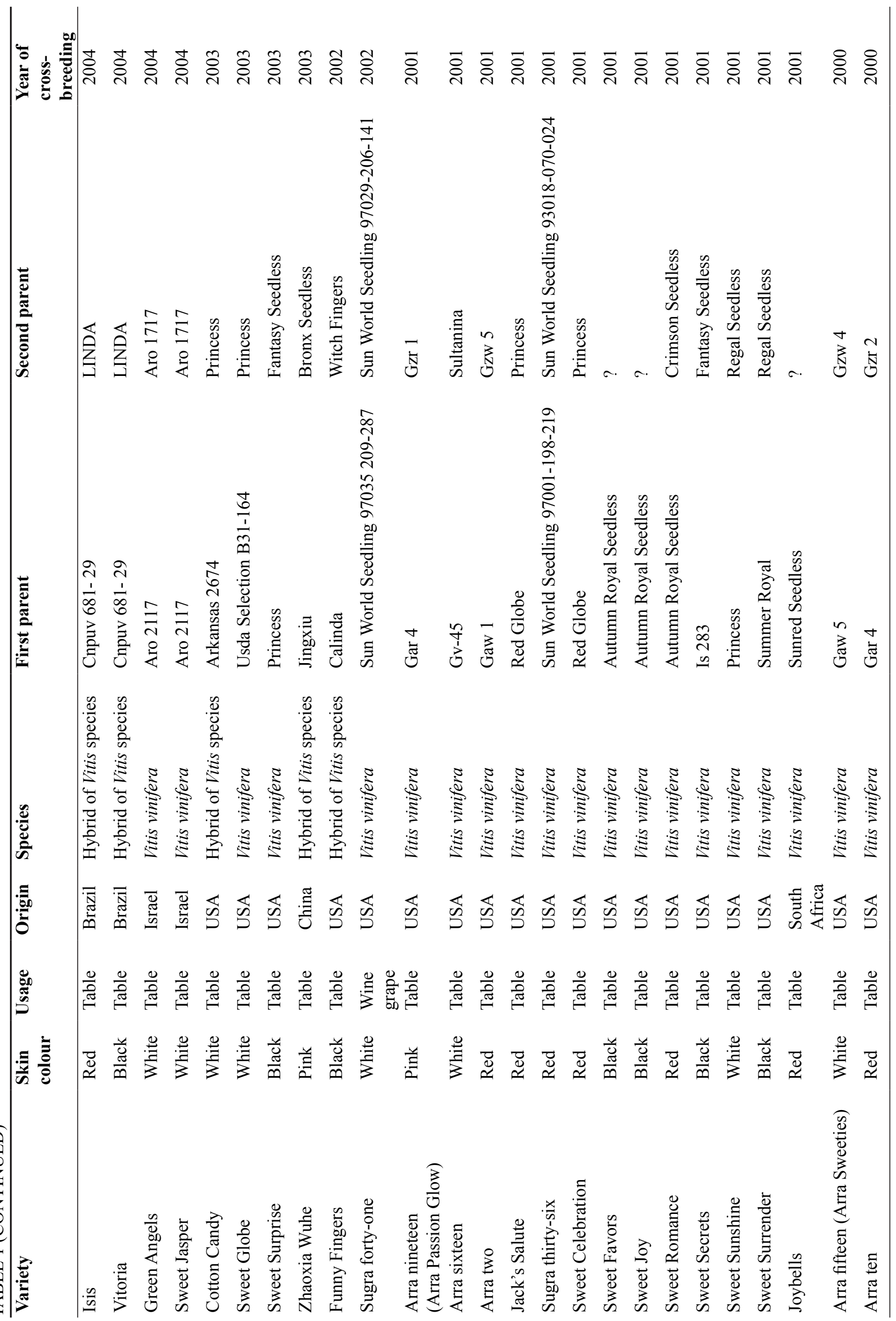




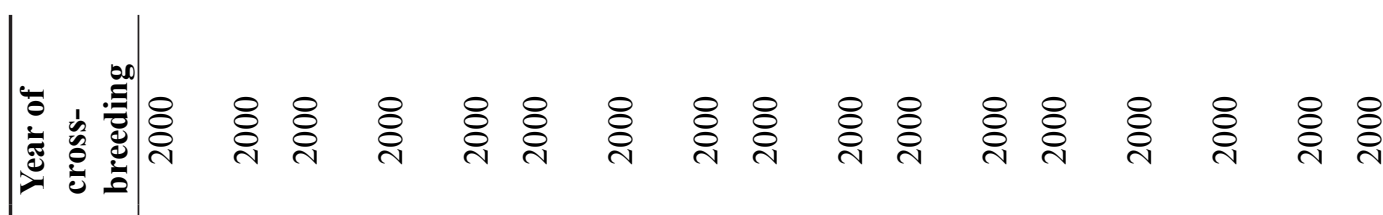

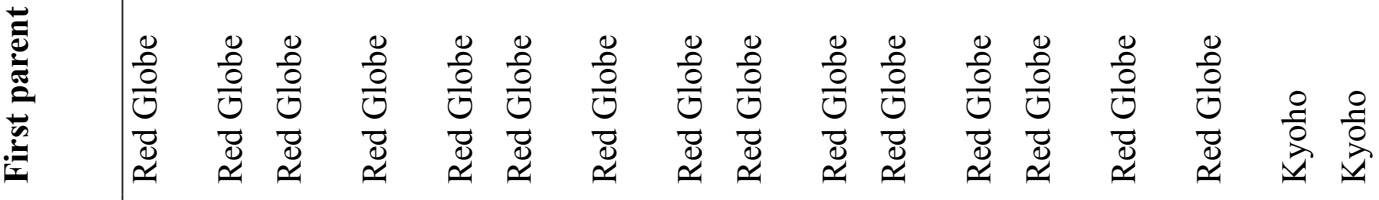

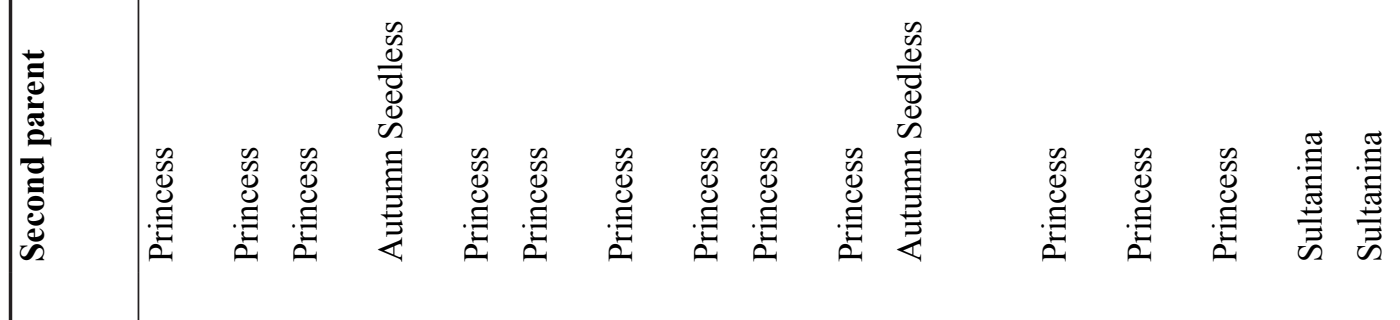

$\begin{array}{rl} & 0 \\ 0 & 0 \\ 0 \\ 0\end{array}$

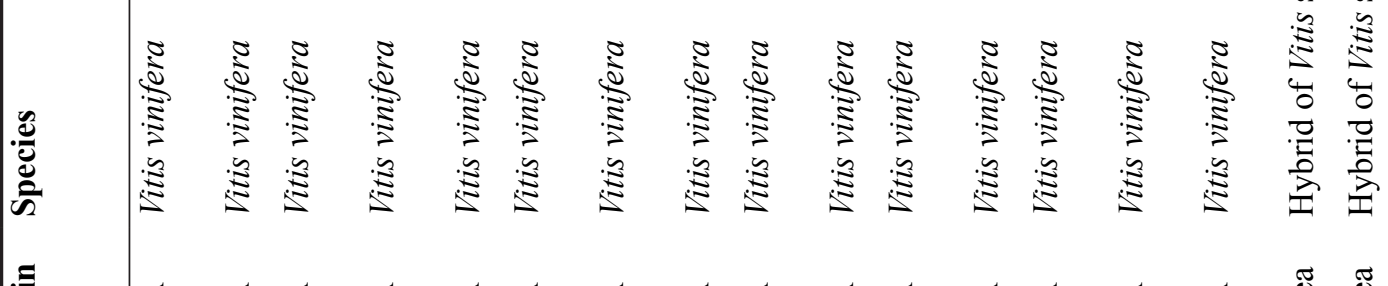

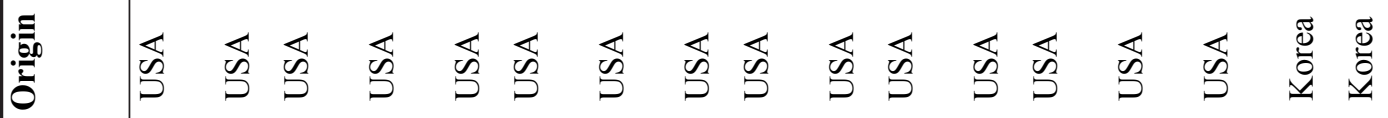

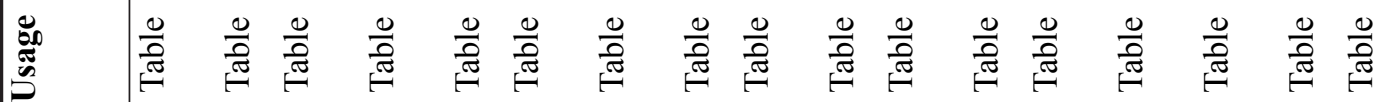

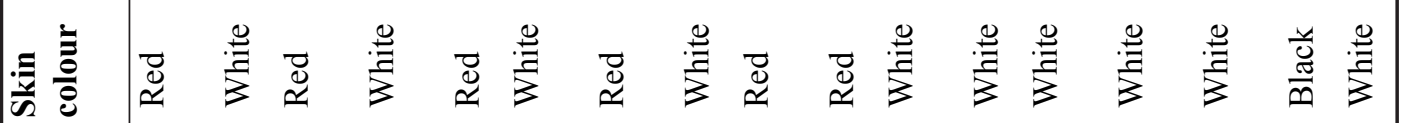

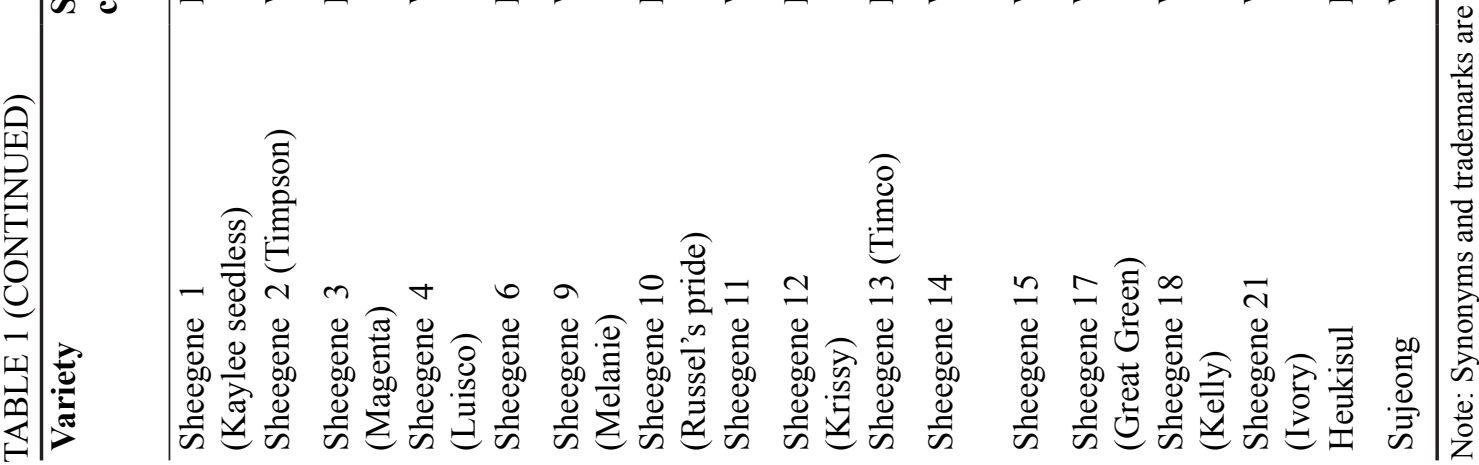


new seedless varieties are ongoing in all countries involved in viticulture business in accordance with their economic priorities.

\section{LITERATURE CITED}

Adam-Blondon, A.F., Lahogue, F., Bouquet, A., Boursiquot, J.M. \& This, P., 2001. Usefulness of two SCAR markers for marker-assisted selection of seedless grapevine cultivars. Vitis 40(3), 147-155.

Akkurt, M., Çakır, A., Shidfar, M., Mutaf, F. \& Söylemezoğlu, G., 2012. Using seedlessness-related molecular markers in grapevine breeding for seedlessness via marker-assisted selection (MAS) into Muscat of Hamburg $\times$ Sultani Progeny. Turk. J. Biol. 37, 101-105.

Bergamini, C., Cardone, M.F., Anaclerio, A., Perniola, R., Pichierri, A., Genghi, R., Alba, V., Forleo, L.R., Caputo, A.R., Montemurro, C., Blanco, A. \& Antonacci, D., 2013. Validation assay of p3 VvAGL11 marker in a wide range of genetic background for early selection of stenospermocarpy in Vitis vinifera L. Mol. Biotechnol. 54(3), 1021-1030.

Bouquet, A. \& Danglot, Y., 1996. Inheritance of seedlessness in grapevine (Vitis vinifera L.). Vitis 35, 35-42.

Cabezas, J.A., Cervera, M.T., Ruiz-Garcia, L., Carreno, J. \& MartinezZapater, J.M., 2006. A genetic analysis of seed and berry weight in grapevine. Genome 49(12), 1572-1585.

Constantinescu, G.A., Pena, A. \& Indreas, A., 1972. Inheritance of some qualitative and quantitative characters in the progeny of crosses between functionally female (gynodynarnic) and apyrene (androdynamic) varieties. [Romanian] Probl. Genet. Teoret. Appl. 7, 213-241.

Costantini, L., Battilana, J., Lamaj, F., Fanizza, G. \& Grando, M.S., 2008. Berry and phenology-related traits in grapevine (Vitis vinifera L.): From quantitative trait loci to underlying genes. BMC Plant Biol. 8, 38 . doi:10.1186/1471-2229-8-38

Costantini, L., Grando, M.S., Feingold, S., Ulanovsky, S., Mejía, N., Hinrichsen, P., Doligez, A., This, P., Cabezas, J.A. \& Martinez-Zapater, J.M., 2007. Generation of a common set of mapping markers to assist table grape breeding. Am. J. Enol. Viticult. 58(1), 102-111.

Dai, Z.W., Ollat, N., Gomès, E., Decroocq, S., Tandonnet, J.P., Bordenave, L., Pieri, P., Hilbert, G., Kappel, C., Van Leeuwen, C., Vivin, P. \& Delrot, S., 2011. Ecophysiological, genetic, and molecular causes of variation in grape berry weight and composition: A review. Am. J. Enol. Viticult. 62(4), 413-425.

Değirmenci, D. \& Marasalı Kunter, B., 2007. Üzümlerde çekirdeksizlik ve 1slah amaçlı kullanımı [Seedlessness in grapes and its use in breeding]. Alatarım 10, 10-17.

Doligez, A., Bouquet, A., Danglot, Y., Lahogue, F., Riaz, S., Meredith, C.P., Edwards. K.J. \& This, P., 2002. Genetic mapping of grapevine (Vitis vinifera L.) applied to the detection of QTLs for seedlessness and berry weight. Theor. Appl. Genet. 105, 780-795.

Fanizza, G., Lamaj, F., Costantini, L., Chaabane, R. \& Grando, M.S., 2005. QTL analysis for fruit yield components in table grapes (Vitis vinifera). Theor. Appl. Genet. 111(4), 658-664.

Ji, W. \& Wang, Y., 2013. Breeding for seedless grapes using Chinese wild Vitis spp. II. In vitro embryo rescue and plant development. J. Sci. Food Agric. 93(15), 3870-3875.

Julius Kühn Institute, 2018a. Autumn Royal Seedless. Online: http://www. vivc.de/index.php?r=passport\%2Fview\&id=17651 [accessed 27 December 2018].
Julius Kühn Institute, 2018b. History of the database. Online: http://www. vivc.de/ [accessed 29 December 2018].

Karaağac, E., Vargas, A.M., De Andrés, M.T., Carreño, I., Ibáñez, J., Carreño, J. \& Cabezas, J.A., 2012. Marker assisted selection for seedlessness in table grape breeding. Tree Genet. Genomes 8(5), 1003-1015.

Lahogue, F., This, P. \& Bouquet, A., 1998. Identification of a codominant scar marker linked to the seedlessness character in grapevine. Theor. Appl. Genet. 97(5), 950-959.

Ledbetter, C.A. \& Burgos, L., 1994. Inheritance of Stenospermocarpic seedlessness in Vitis vinifera L. J. Hered. 85(2), 157-160.

Li, G.R., Ji, W., Wang, G., Zhang, J.X. \& Wang, Y.J., 2014. An improved embryo-rescue protocol for hybrid progeny from seedless Vitis vinifera grapes $\times$ wild Chinese Vitis species. In Vitro Cell Dev. Biol. Plant. 50(1), 110-120.

Li, Z., Li, T., Wang, Y. \& Xu, Y., 2015. Breeding new seedless grapes using in ovulo embryo rescue and marker-assisted selection. In Vitro Cell Dev. Biol. Plant. 51, 241-248.

Mejía, N. \& Hinrichsen, P., 2003. A new, highly assertive SCAR marker potentially useful to assist selection for seedlessness in table grape breeding. VIII International Conference on Grape Genetics and Breeding. Acta Hortic. $603,559-564$

Mejía, N., Gebauer, M., Munoz, L., Hewstone, N., Munoz, C. \& Hinrichsen, P., 2007. Identification of QTLs for seedlessness, berry size, and ripening date in a seedless x seedless table grape progeny. Am. J Enol. Vitic. 58(4), 499-507.

Mejía, N., Soto, B., Guerrero, M., Casanueva, X., Houel, C., Miccono, M.A., Ramos, R., Le Cunff, L, Boursiquot, J.M., Hinrichsen, P. \& AdamBlondon, A.F., 2011. Molecular, genetic and transcriptional evidence for a role of VvAGL11 in stenospermocarpic seedlessness in grapevine. BMC Plant Biol. 11:57. doi:10.1186/1471-2229-11-57

Perl, A., Sahar, N., Spiegel-Roy, P., Gavish, S., Elyası, R., Orr, E. \& Bazak, H., 2000. Conventional and biotechnological approaches in breeding seedless table grapes. Acta Hortic. 528, 613-618.

Perl, A., Sahar, N., Eliassi, R., Baron, P., Spiegel-Roy, P. \& Bazak, H., 2003. Breeding of new seedless table grapes in Israel conventional and biotechnological approach. Acta Hortic. 623, 185-187.

Ramming, D.W., 1990. The use of embryo culture in fruit breeding. HortScience. 25(4), 393- 398

Ramming, D.W., Emershad, R.L. \& Tarailo, R., 2000. A stenospermocarpic, seedless Vitis vinifera $\mathrm{x}$ Vitis rotundifolia hybrid developed by embryo rescue. HortScience 35(4), 732-734.

Sato, A., Yamane, H., Yamada, M. \& Yoshinaga, K., 1994. Inheritance of seedlessness in grapes. [Japan.] J. Japan Soc. Hort. Sci. 63, 1-7.

Spiegel-Roy, P., Baron, Y. \& Sahar, N., 1990. Inheritance of seedlessness in seeded $\mathrm{x}$ seedless progeny of Vitis vinifera $\mathrm{L}$. Vitis 29, 79-83.

Tian, L. \& Wang. Y., 2008. Seedless grape breeding for disease resistance by using embryo rescue. Vitis 47(1), 15-19.

Uquillas, C., Torres, E., Ibacache, A. \& Defilippi, B.G., 2013. 'Iniagrapeone', a new Chilean table grape cultivar. HortScience 48(4), 501-503.

Yang, D., Li, W., Li, S., Yang, X., Wu, J. \& Cao, Z., 2007. In vitro embryo rescue culture of $\mathrm{F} 1$ progenies from crosses between diploid and tetraploid grape varieties. Plant Growth Regul. 51(1), 63-71. 